\title{
Pregled bolničkih infekcija i najčeščih uzročnika u multidisciplinarnoj jedinici za intenzivno liječenje u državi sa srednjim do visokim dohotkom
}

\author{
Hospital infections and predominant pathogens in multidisciplinary intensive care unit in an \\ upper middle income country
}

Mirko Mihalj, Dajana Vladić, Boris Matić, Zoran Karlović

Odjel za anesteziju, reanimaciju i intenzivno liječenje, Sveučilišna klinička bolnica Mostar, Bosna i Hercegovina

\author{
Ključne riječi: \\ bolničke infekcije \\ intenzivno liječenje \\ etiologija \\ Keywords: \\ hospital infections \\ critical care \\ etiology
}

Primljeno: 11.6.2019.

Received: 11.6.2019.

Prihvaćeno: 30.9.2019.

Accepted: 30.9.2019.

$\bowtie$ Adresa za dopisivanje:

Mirko Mihalj

Kneza Trpimira 14, Mostar, BiH.

e-mail:mmmihalj@gmail.com

\begin{abstract}
Sažetak
Uvod: Cilj je ovog istraživanja utvrditi pojavnost bolničkih infekcija u multidisciplinarnoj jedinici za intenzivno liječenje (JIL) Sveučilišne kliničke bolnice Mostar i ustanoviti koji su patogeni mikroorganizmi najčešći uzročnici istih.

Ispitanici i metode: $U$ ovu retrospektivnu studiju uključeni su pacijenti hospitalizirani u JIL-u duže od 48 sati, u razdoblju od 1.1.2017. do 31.12.2017. godine. Za analizu su korišteni uzorci hemokultura, urinokultura i bronhoaspirata koji su uzimani 48 sata nakon prijema bolesnika u JIL. Svi su podaci preuzeti iz informaciijkkog bolničkog sustava, a za analizu su korištene deskriptivne statističke metode.

Rezultati: Od ukupno 644 bolesnika primljenih u JIL u datom razdoblju, 277 je odgovaralo postavljenim kriterijima, od kojih je pak 70 (25,27\%) sa stopom 33,3/1000 bolesničkih dana bilo s potvrđenom bolničkom infekcijom (BI). Od navedenih bolesnika, 13 (18,57\%) je imalo infekciju dvaju organskih sustava, dok su kod 5 (7,15\%) bolesnika klinički uzročnici dokazani u trima organskim sustavima. Prevladavale su infekcije respiratornog sustava (54,84\%) - sa stopom 18,3/1000, potom infekcije mokraćnog sustava (26,88\%) - sa stopom 8,9/1000, a najrjeđe su dokazane infekcije krvotoka (18,28\%) - sa stopom 6,1/1000. Acinetobacter baumannii i Pseudomonas aeruginosa bili su najčešći uzročnici respiratornih infekcija i infekcija krvotoka. Najčěšci uzročnici urinarnih infekcija su Enterococcus spp i Candida albicans.
\end{abstract}

Zaključak: Bolničke infekcije značajan su zdravstveni problem koji povećava morbiditet i mortalitet bolesnika, naročito u jedinicama za intenzivno liječenje te je, stoga, potrebno poduzeti značajne mjere kako bi se smanjila njihova učestalost. Prema rezultatima našeg istraživanja, zastupljenost infekcija respiratornog sustava u JlL-u viša je nego u većini drugih sličnih istraživanja.

\section{Abstract}

Introduction: The aim of this study was to determine the occurrence of hospital infections in the multidisciplinary intensive care unit (ICU) of the Mostar University Clinical Hospital and the most common pathogenic microorganisms causing them.

Methods: This retrospective study involved patients admitted to the ICU for more than 48 hours, from January 1, 2017 to December 31, 2017. Blood cultures, urinary cultures and bronchial aspirate samples were used for analysis, taken 48 hours after admission to the ICU. All data were collected from the information hospital system, and descriptive statistical methods were used for the purpose of conducting the analysis.

Results: Out of 644 patients admitted to the ICU in the given period, 277 were included in our study, out of whom 70 (25.27\%), with a rate of 33.3/1000 hospital days, had at least one confirmed hospital infection. Altogether 13 patients (18.57\%) had an infection in two organ systems, while 5 (7.15\%) patients had positive microbiological samples in three organ systems. Predominant clinical form of infections in these patients were respiratory infections (54.84\%) - with a rate of $18.3 / 1000$, then urinary tract infections $(26.88 \%)$ - with a rate of 8.9/1000 and bloodstream infections (18.28\%) - with a rate of 6.1/1000. Acinetobacter baumannii and Pseudomonas aeruginosa were the most common cause of respiratory and bloodstream infections, while urinary infections were caused mostly by Enterococcus spp and Candida albicans.

Conclusion: Hospital infections remain a major health problem that increases the morbidity and mortality of patients, especially in intensive care units and therefore, significant measures should be taken to reduce their incidence. Respiratory infections in our ICU are the most common, with higher incidence rate than in most other similar studies. 


\section{Uvod}

Bolničke infekcije (BI) predstavljaju značajan zdravstveni problem koji povećava morbiditet, mortalitet, troškove liječenja i produžuje tijek liječenja bolesnika, naročito u jedinicama za intenzivno liječenje (JIL). Problem bolničkih infekcija prisutan je, kako u razvijenim, tako i u državama u razvoju, iako u potonjim predstavlja veću prijetnju po sigurnost bolesnika zbog veće prevalencije multiplo-rezistentnih (MDR) bakterija. ${ }^{1}$

Značajnu ulogu u incidenciji bolničkih infekcija čine jedinice za intenzivno liječenje, naročito multidisciplinarne, u kojima se primjenjuje značajan broj invazivnih dijagnostičko-terapijskih metoda. Nadalje, bolesnici u JIL-u često su imunokompromitirani i imaju predispoziciju za infekcije, što je posljedica, kako ozbiljnosti osnovne bolesti zbog koje su zaprimljeni u JIL, tako i komorbiditeta. U ovih bolesnika dolazi do otpuštanja interleukina 10 i drugih protuupalnih medijatora $^{2}$, kao što su antagonisti interleukin 1 receptora i receptora tumor nekrotizirajućeg čimbenika koji dovode do stanja koje se često naziva imunoparalizom. ${ }^{3}$ Primjenom velikog broja invazivnih procedura i uređaja (središnji venski kateter, strojna ventilacija, urninarni kateter, arterijska linija, itd.) dolazi do narušavanja prirodnih anatomskih barijera (koža, sluznice i sl.), kao i obrambenih mehanizama organizma. Primjerice, endotrahealna intubacija i strojna ventilacija, djelomično ili u potpunosti, potiskuju prirodne obrambene mehanizme (kašljanje, kihanje, mukocilijarna pokretljivost sluznice dišnog sustava), što kod ovakvih bolesnika olakšava razvoj infekcija dišnog sustava. Nerijetka uporaba imunosupresivnih lijekova, kao i antibiotika širokog spektra koji doprinose razvoju mikroorganizama rezistentnih na antibiotike značajno utječu na pojavnost bolničkih infekcija.

Uzročnici većine BI uglavnom su MDR bakterije koje nisu dio mikrobiote, a najčešće su za njihov prijenos odgovorni zdravstveni djelatnici. Tijekom 90-ih godina prošlog stoljeća, glavni uzročnici bolničkih infekcija bile su gram pozitivne bakterije (meticilin rezistentni Staphylococcus aureus, enterokoki, koagulaza negativni stafilokoki). Prvenstveno su se javljale infekcije krvotoka i kirurških rana. Veća učestalost infekcija uzrokovanih gram pozitivnim bakterijama posljedica je uporabe antibiotika u profilaktičke svrhe, kao i veći broj laparoskopskih operacija koje su smanjile učestalost infekcija kirurških rana vezanih uz abdominalne zahvate. ${ }^{4}$ Međutim, u današnje doba, glavni uzročnici bolničkih infekcija su gram negativne bakterije, koje su često multiplo rezistentne (npr. Acinetobacter baumannii).

\section{Materijali i metode}

U ovu su retrospektivnu studiju uključeni bolesnici koji su hospitalizirani u multidisciplinarnoj JIL Odjela za anesteziju, reanimaciju i intenzivno liječenje Sveučilišne kliničke bolnice Mostar, kapaciteta od 12 kreveta s aparatima za strojnu ventilaciju, u razdoblju od 1 . siječnja 2017. do 31. prosinca 2017. godine. U studiju su uključeni svi bolesnici dobnog raspona od 18 do 98 godina koji su boravili u našem JIL-u duže od 48 sati. Bolesnici kod kojih je smrtni ishod nastupio unutar prvih 48 sati, kao i oni koji su boravili u JIL-u kraće od 48 sati isključeni su iz daljnjeg istraživanja. Po prijemu u JIL, sve je bolesnike pregledao nadležni liječnik te je učinjena dijagnostičko-terapijska obrada.

Dijagnoza bolničkih infekcija i njihova anatomska lokalizacija postavljena je na osnovu standardnih definicija i preporuka Centra za kontrolu i prevenciju bolesti (Centers for Disease Control and Prevention CDC), Atlanta, SAD. ${ }^{5} \mathrm{U}$ skladu s navedenim definicijama, bolničkom smo infekcijom smatrali onu koja se klinički manifestirala najkraće 48 sati nakon prijema u JIL i najdulje 48 sati nakon otpusta iz JIL-a.

Osnovni korišteni pokazatelji razvoja bolničke infekcije standardni su upalni parametri (C-reaktivni protein $>5 \mathrm{mg} / \mathrm{l}$, i $/$ ili bijela krvna zrnca $<4 \times 10^{9} / \mathrm{L}$ odnosno $\left.>10 \times 10^{9} / \mathrm{L}\right)$ i prisustvo povišene tjelesne temperature $\left(>38^{\circ} \mathrm{C}\right)$. Kako bismo potvrdili prisustvo infekcije dišnog sustava koristili smo rendgenogram prsnog koša kojim se dokazuje prisustvo novonastalih promjena plućnog parenhima ili pleuralnog izljeva te izolacija uzročnika iz bronhalnog aspirata uzorkovanog fleksibilnim fiberoptičkim bronhoskopom. ${ }^{6}$ Kako bismo dokazali prisustvo infekcije urinarnog sustava koristili smo, pored upalnih pokazatelja, izolaciju patogenog mikroorganizma u uzorku urina iz novopostavljenog trajnog urinarnog katetera. ${ }^{7}$ Kako bismo dokazali prisustvo infekcija krvotoka koristili smo, pored osnovnih upalnih pokazatelja, izolaciju uzročnika iz uzorka hemokultura. ${ }^{8} \mathrm{U}$ slučaju potvrđene BI, kontrolni mikrobiološki uzorci uzimani su u intervalima od 7 dana. ${ }^{9}$

Svi podaci o bolesniku, laboratorijskim nalazima te mikrobiološkim pretragama preuzeti su iz bolesničkih kartona i bolničkog informacijskog sustava. Pored mikrobioloških, prezentirani su i osnovni demografski podatci. U svrhu analize prikupljenih podataka primijenjene su deskriptivne statističke metode.

\section{Rezultati}

Tijekom razdoblja promatranja u multidisciplinarnoj JIL Sveučilišne kliničke bolnice Mostar liječeno je ukupno 644 bolesnika, od kojih je 277 zadovoljavalo 
kriterije. Prosječna dob pacijenata bila je $63,77 \pm 17,05$ godina. U obuhvaćenoj populaciji je bio nešto veći broj $(\mathrm{n}=166 ; 59,93 \%)$ pripadnika muškog spola (Tablica 1$)$.

Ukupno je ostvareno 2787 bolesničkih dana (Tablica 1), 1933 dana strojne ventilacije, 2533 dana sa središnjim venskim kateterom i 2752 dana s urinarnim kateterom (Tablica 2).

Kod 70 od ukupno 277 pacijenata $(25,27 \%$, sa stopom 33,3/1000 bolesničkih dana) dijagnosticirana je bolnička infekcija. BI jednog organskog sustava imalo je 52 pacijenata $(74,28 \%)$, njih trinaest $(18,57 \%)$ je imalo BI dvaju organskih sustava, dok je kod pet $(7,15 \%)$ bolesnika BI dijagnosticirana u trima organskim sustavima. Najčešće su infekcije bile respiratorne (54,84\%), sa stopom infekcije $18,3 / 1000$ bolesničkih dana (BD) odnosno 26,38/1000 dana strojne ventilacije, potom infekcije mokraćnog sustava $(26,88 \%)$, sa stopom 8,9/1000 BD odnosno 9,08/1000 dana urinarnog katetera. Infekcije krvotoka bile su najrjeđe
(18,28\%), sa stopom 6,1/1000 BD odnosno 6,71/1000 dana središnjeg venskog katetera (Tablica 2).

$\mathrm{U}$ datom je periodu analizirano 435 mikrobioloških uzoraka, od kojih je 215 (49,42\%) bilo pozitivno. Ukupno je izolirano 272 uzročnika koji su povezani s BI, a prikazani su u Tablici 3. Najčešći su uzročnici svih BI bili gram negativni mikroorganizmi $(73,16 \%)$, među kojima dominiraju Acinetobacter baumannii $(27,58 \%)$, Pseudomonas aeruginosa $(16,54 \%)$ i Serratia spp $(9,93 \%)$. Oni su ujedno i najčešći uzročnici infekcija respiratornog sustava i krvotoka. Najčešći uzročnici infekcija mokraćnog sustava bili su gram pozitivni mikroorganizmi (64,28\%), Enterococcus spp i Candida albicans u skoro jednakim omjerima (oko 30\%) dok su od gram negativnih uzročnika najčešće izolirani Acinetobacter baumannii i Proteus mirabillis (8,33\% oboje) te Escherichia coli $(7,15 \%)$.

Tablica 4. prikazuje najčešće izolirane bakterijske mikroorganizme i rezistenciju na antibiotike.

TABLICA 1. OSNOVNI DEMOgRAFSKI PODACI PACIJENATA U JEDINICI ZA INTENZIVNO LIJEČENJE

TABLE 2. BASIC DEMOGRAPHIC DANA OF PATIENTS ADMITTED TO THE INTENSIVE CARE UNIT

\begin{tabular}{|c|c|c|c|c|}
\hline \multicolumn{2}{|c|}{ Varijabla } & Bolesnici sa BI; n (\%) & Bolesnici bez BI; n (\%) & ukupno \\
\hline \multicolumn{2}{|c|}{ Bolesnici } & $70(25,27 \%)$ & $207(74,73 \%)$ & 277 \\
\hline \multicolumn{2}{|c|}{ Godine (raspon) } & $18-98$ & $18-97$ & $18-98$ \\
\hline \multicolumn{2}{|c|}{ Godine (prosjek) $\pm \mathrm{SD}^{*}$} & $65,16 \pm 17,53$ & $63,3 \pm 16,9$ & $63,77 \pm 17,05$ \\
\hline \multicolumn{2}{|c|}{ Stariji $\geq 65$ godina } & $40(57,14 \%)$ & $109(52,65 \%)$ & $149(53,79 \%)$ \\
\hline \multirow[t]{2}{*}{ Spol } & M & $42(60 \%)$ & $124(59,9 \%)$ & $166(59,93 \%)$ \\
\hline & $\check{\mathrm{Z}}$ & $28(40 \%)$ & $83(40,1 \%)$ & $111(40,07 \%)$ \\
\hline \multicolumn{2}{|c|}{ Broj bolesničkih dana u JIL-u } & $1504(53 \%)$ & $1283(47 \%)$ & 2787 \\
\hline
\end{tabular}

${ }^{\star} \mathrm{SD}$ - standardna devijacija

Tablica 2. Pregled bolničKiH INFEKCIJA I INVAZIVNiH Procedura U JIL-U

TABle 2. Overview of hospital infeCtions AND INVASIVE PRocedures at ICU

\begin{tabular}{|c|c|c|c|c|c|c|}
\hline \multicolumn{2}{|c|}{ Bolničke infekcije } & \multicolumn{3}{|c|}{ Invazivne procedure u JIL-u } \\
\hline Organski sustav & $\mathrm{n}^{*}(\%)$ & $\begin{array}{c}\text { Stopa infekcija } \\
\text { na } 1000 \mathrm{BD} \dagger\end{array}$ & $\begin{array}{c}\text { Invazivne } \\
\text { procedure }\end{array}$ & $\begin{array}{c}\text { Broj bolesničkih } \\
\text { dana }\end{array}$ & $\begin{array}{c}\text { Omjer invazivnih } \\
\text { procedura u ukupnom } \\
\text { broju BD } \ddagger\end{array}$ & $\begin{array}{c}\text { Stopa infekcija (na } \\
1000 \text { dana invazivne } \\
\text { procedure) }\end{array}$ \\
\hline $\begin{array}{c}\text { Respiratorne in- } \\
\text { fekcije }\end{array}$ & $51(54,84)$ & $18,3 / 1000$ & Strojna ventilacija & 1933 & 0,69 & $26,38 / 1000$ \\
\hline $\begin{array}{c}\text { Infekcije krvotoka } \\
\text { Infekcije }\end{array}$ & $17(18,28)$ & $6,1 / 1000$ & $\begin{array}{c}\text { Središnji venski } \\
\text { kateter }\end{array}$ & 2533 & 0,9 & $6,71 / 1000$ \\
\hline mokraćnog sustava & $25(26,88)$ & $8,9 / 1000$ & Urinarni kateter & 2752 & 0,98 & $9,08 / 1000$ \\
\hline Ukupno & $93(100)$ & $33,3 / 1000$ & & & \\
\hline
\end{tabular}

${ }^{*}$ višestruke infekcije na istom organskom sustavu u istog bolesnika su predstavljene kao jedna

$\dagger$ bolesnički dani

$\ddagger$ device utilisation ratio 
TABlicA 3. Pregled IZOLIRANIH UZRoČNiKA POVEZANiH S BOLNIČKIM INFEKCIJAMA

TABle 3. OverviEW OF ISOLATED PATHOGENS ASSOCIATED WITH NOSOCOMIAL INFECTIONS

\begin{tabular}{|c|c|c|c|c|c|c|c|c|}
\hline \multirow[b]{3}{*}{ Uzročnik } & \multicolumn{8}{|c|}{ Uzročnici bolničkih infekcija ${ }^{\star}$} \\
\hline & \multicolumn{2}{|c|}{ Dišne infekcije } & \multicolumn{2}{|c|}{ Infekcije krvotoka } & \multicolumn{2}{|c|}{ IMS $\dagger$} & \multicolumn{2}{|c|}{ Ukupno } \\
\hline & $\operatorname{Broj}(\mathrm{n})$ & $\%$ & Broj (n) & $\%$ & Broj (n) & $\%$ & Broj (n) & $\%$ \\
\hline Gram-negativni & 112 & 94,11 & 57 & 82,6 & 30 & 35,72 & 199 & 73,16 \\
\hline Acinetobacter baumannii & 53 & 44,53 & 15 & 21,74 & 7 & 8,33 & 75 & 27,58 \\
\hline Serratia spp & 11 & 9,24 & 13 & 18,85 & 3 & 3,57 & 27 & 9,93 \\
\hline Pseudomonas aeruginosa & 29 & 24,36 & 12 & 17,39 & 4 & 4,77 & 45 & 16,54 \\
\hline Klebsiella pneumoniae & 6 & 5,04 & 8 & 11,59 & 3 & 3,57 & 17 & 6,26 \\
\hline Proteus mirabillis & 5 & 4,3 & 2 & 2,89 & 7 & 8,33 & 14 & 5,14 \\
\hline Stenotrophomonas maltophillia & & & 6 & 8,69 & & & 6 & 2,2 \\
\hline Escherichia coli & 3 & 2,52 & 1 & 1,45 & 6 & 7,15 & 10 & 3,67 \\
\hline Ostali uzročnici & 5 & 4,3 & & & & & 5 & 1,84 \\
\hline Gram-pozitivni & 7 & 5,89 & 12 & 17,4 & 54 & 64,28 & 73 & 26,84 \\
\hline Enterococcus spp & 3 & 2,52 & 3 & 4,35 & 27 & 32,14 & 33 & 12,13 \\
\hline Candida albicans & & & 9 & 13,05 & 25 & 29,76 & 34 & 12,5 \\
\hline Staphylococcus aureus & 4 & 3,37 & & & & & 4 & 1,47 \\
\hline Ostali uzročnici & & & & & 2 & 2,38 & 2 & 0,74 \\
\hline Ukupno & 119 & & 69 & & 84 & & 272 & 100 \\
\hline
\end{tabular}

* U ukupan broj su uračunati svi pozitivni mikrobiološki nalazi

$\dagger$ Infekcije mokraćnog sustava

TAblica 4. Prikaz RezistenciJe BAKTerijskih UZRočnika NA ANTibiotike

Table 4. Antibiotic Resistance of Bacterial pathogens

\begin{tabular}{|c|c|c|c|c|c|c|c|c|c|}
\hline & 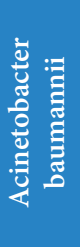 & 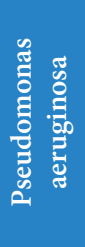 & 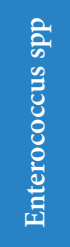 & $\begin{array}{l}\text { है } \\
\text { क्ञ } \\
\text { है } \\
\text { है } \\
\text { है }\end{array}$ & 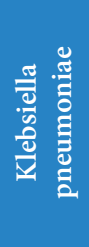 & 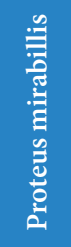 & 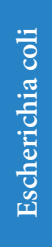 & 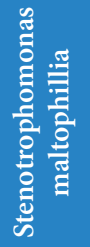 & 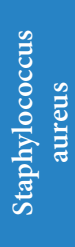 \\
\hline \multicolumn{10}{|l|}{ - cefalosporini: } \\
\hline ceftazidim & 98,2 & 6,7 & I & 100 & 100 & 64,3 & 70 & I & I \\
\hline ceftriakson & 98,4 & 49 & I & 100 & 100 & 71,4 & 90 & I & l \\
\hline cefuroksim & 100 & 75,6 & I & 100 & 88,3 & 71,4 & 70 & l & l \\
\hline cefoperazon & 100 & 0 & I & 77 & 47 & 0 & 50 & 0 & I \\
\hline cefotaksim & 100 & 33 & / & 79 & 70,6 & 35,7 & 80 & 100 & l \\
\hline cefepim & 1 & 0 & / & I & / & 0 & I & I & l \\
\hline cefazolin & 1 & I & I & 100 & I & 50 & I & I & I \\
\hline \multicolumn{10}{|l|}{ - aminoglikozidi: } \\
\hline amikacin & 64,7 & 11,3 & 9,1 & 0 & 5,9 & 33,3 & 0 & 0 & I \\
\hline gentamicin & 96,2 & 41 & 66,6 & 81,5 & 100 & 78,6 & 60 & l & 0 \\
\hline tobramicin & / & 28 & / & I & I & 1 & l & 0 & l \\
\hline netilmicin & I & 16 & I & I & l & I & l & 0 & I \\
\hline \multicolumn{10}{|l|}{ - karbapenemi: } \\
\hline imipenem & 94,8 & 17,2 & I & 0 & 0 & 0 & 0 & 100 & I \\
\hline ertapenem & 100 & 84,4 & I & 0 & 0 & 0 & 0 & 100 & I \\
\hline meropenem & 100 & 38,2 & I & 0 & 0 & 0 & 0 & 100 & l \\
\hline \multicolumn{10}{|l|}{ - ostali $\beta$ laktamski antibiotici: } \\
\hline
\end{tabular}




\begin{tabular}{|c|c|c|c|c|c|c|c|c|c|}
\hline ampicilin & / & / & 24,3 & l & l & & & l & l \\
\hline ampicillin + sulbaktam & 11,1 & I & I & 100 & 100 & 85,7 & 80 & 100 & 1 \\
\hline amoksicilin & 100 & 100 & 39,4 & 100 & 100 & 100 & 100 & / & 0 \\
\hline amoksicilin + klavulonska kiselina & 100 & 100 & 36,4 & 100 & 82,4 & 78,6 & 100 & 100 & 0 \\
\hline piperacillin & 96,4 & 10,2 & l & 81,8 & 88,3 & 71,4 & 50 & 100 & l \\
\hline piperacillin + tazobaktam & 93,5 & 0 & l & 18,2 & 35,3 & 0 & 0 & 100 & I \\
\hline - fluorkinoloni: & & & & & & & & & \\
\hline ciprofloksacin & 100 & 42 & 60,6 & 88,9 & 82,4 & 35,7 & 80 & 0 & 1 \\
\hline levofloksacin & 100 & 49 & I & 0 & 0 & 0 & / & I & / \\
\hline norfloksacin & 100 & l & I & 0 & 0 & I & l & I & 1 \\
\hline teikoplanin & I & I & 27,3 & I & I & I & I & I & 1 \\
\hline vankomicin & I & / & 21,2 & / & l & I & I & l & l \\
\hline klindamicin & I & I & I & I & I & I & I & I & 0 \\
\hline eritromicin & I & I & I & I & I & I & I & I & 0 \\
\hline linezolid & I & I & 0 & I & I & l & I & I & l \\
\hline kolistin & 0 & 0 & I & 18,7 & 0 & 100 & 0 & 100 & I \\
\hline rifampin & 32,7 & 51 & I & 100 & 64,7 & 50 & I & I & I \\
\hline nitrofurantoin & 100 & I & 30,3 & 14,8 & l & 100 & I & 100 & I \\
\hline trimetoprim + sulfametoksazol & 83 & 67 & l & 77,8 & 47 & 71,4 & 60 & 0 & l \\
\hline fosfomicin + glukoza-6-fosfat & 80 & I & I & 0 & 0 & 0 & I & I & I \\
\hline
\end{tabular}

/ - Uzročnik nije ispitivan na navedeni antibiotik

\section{Rasprava}

Učestalost BI u jedinicama intenzivnog liječenja u literaturi i dostupnim studijama varira od 9\% $37 \%{ }^{10,11}$. Mogući razlozi širokog raspona učestalosti BI su: financijski (incidencija BI je znatno viša u državama s niskim bruto nacionalnim dohotkom po glavi stanovnika ${ }^{12} \mathrm{u}$ odnosu na one sa srednjim i visokim) te vrsta JIL-a odnosno osobitosti pacijenata koji se liječe u njemu. Specijalizirane jedinice za intenzivno liječenje (kardiovaskularna, neurološka i sl.) općenito prijavljuju nižu incidenciju bolničkih infekcija ${ }^{10,13,14,15}$ u odnosu na multidisciplinarne jedinice za intenzivno liječenje. ${ }^{16,17,18}$ Učestalost BI veća je u državama $s$ nižim bruto nacionalnim dohotkom (u prosjeku $\geq 25$ \%) u odnosu na Europsku uniju i Sjedinjene Američke Države, ${ }^{1,12}$ iako i tu postoje izuzetci. ${ }^{19}$ Značajnu ulogu u varijabilnosti prezentiranih podataka čini i točna definicija odnosno vrsta infekcije koja se prati u pojedinoj studiji (bolnička infekcija, infekcija nastala u JIL-u, infekcija vezana uz primjenu invazivnih metoda i uređaja i sl).

Prvo veće istraživanje bolničkih infekcija u jedinicama za intenzivno liječenje koje je obuhvatilo veći broj europskih država je EPIC studija iz 1995. godine. ${ }^{20} \mathrm{U}$ spomenutoj se studiji pratila jednodnevna prevalencija bolničkih infekcija u 10038 pacijenata u 1417 jedinica za intenzivno liječenje iz 17 zapadnoeuropskih država (isključujući koronarne i pedijatrijske intenzivne). Prema rezultatima studije, $44 \%$ bolesnika imalo je infekciju, a $21 \%$ od ukupnog broja bolesnika imalo je infekciju zadobivenu u JIL-u, od kojih su najčešće bile pneumonije. Nastavak ovog istraživanja bila je EPIC II $^{21}$ studija iz 2009. godine kojom je obuhvaćeno 14414 bolesnika u 1265 JIL-a iz 75 država svijeta. Prema rezultatima istraživanja, broj bolesnika s infekcijom značajno je visok (51\%), više od 70\% bolesnika u svakom trenutku prima antibiotsku terapiju, a rizik za infekciju povećava se ovisno o dužini boravka u JIL-u. Nadalje, incidencija bolničkih infekcija povezana je s proračunom zdravstvenog sustava odnosno veća je u državama $s$ manjim udjelom novca potrošenim na zdravstvo. U konačnici, rezultati studije ukazuju na usku povezanost BI i većeg morbiditeta.

Prema rezultatima našeg istraživanja, učestalost bolničkih infekcija je 25,27 \% u JIL Sveučilišne kliničke bolnice Mostar, što je na gornjoj granici učestalosti u europskim državama. Međutim, ako napravimo usporedbu s ostalim državama s niskim do srednjim nacionalnim dohotkom, u koje spada i BiH, incidencija je niža. Četvrtina bolesnika s BI ostvarila je više od polovice ukupnog broja bolesničkih dana, potvrđujući povezanost BI i duljine boravka u JIL-u (Tablica 1), što je u skladu sa zaključcima EPIC II studije. ${ }^{21}$ Primjerice, Simonetti ${ }^{22}$ navodi stupanj infekcije od 16,2 \% zahvaćenih pacijenata u dvogodišnjoj studiji provedenoj u JIL-u sveučilišne bolnice u Napulju, dok Lossa u svojoj nacionalnoj studiji navodi učestalost BI od $24 \%$ u Argentini, ${ }^{23}$ Shaikh opisuje učestalost od $29,13 \%$ u 
Pakistanu, ${ }^{24}$ a Merzougui 30,6\% u Tunisu. ${ }^{25}$ Rutkowska i sur. ${ }^{16}$ navode učestalost od $26 \%$ u novootvorenom JIL-u u Poljskoj, što je nešto viši postotak od studije koju je načinio Walaszek ${ }^{26}$ uzevši podatke iz 8 JIL-a u južnoj Poljskoj (22,6\%), dok Vosylius ${ }^{17}$ navodi učestalost od 37\% infekcija zadobivenih u JIL-u u sveučilišnoj bolnici u Litvaniji.

Iz navedenih se podataka može zaključiti kako je visoka incidencija BI značajan problem u velikom broju jedinica za intenzivno liječenje. Najznačajniji čimbenici rizika koji pacijente u JIL-u čine podložnima bolničkim infekcijama mogu se podijeliti u 4 osnovne skupine: čimbenike povezane s postojećim, kroničnim oboljenjima, čimbenike nastale uslijed trenutnog, akutnog oboljenja te rizike povezane uz invazivne procedure i druge modalitete liječenja u JIL-u. ${ }^{2}$ Pojedine studije navode kako dob bolesnika ne utječe na učestalost bolničkih infekcija, ${ }^{27}$ ali se ipak smatra kako su dob bolesnika, kao i neadekvatne higijenske mjere, također, značajni čimbenici koji utječu na učestalost bolničkih infekcija u JIL-u. ${ }^{28}$ Dodatni je problem što većinu BI u JIL-u uzrokuju multiplo rezistentni uzročnici.

U većini JIL, čiji je ustroj sličan našoj, najveći je broj upravo infekcija respiratornog sustava, iako pojedini autori navode infekcije krvotoka ${ }^{18}$ odnosno infekcije mokraćnog sustava ${ }^{13}$ kao najčešće. Broj prijavljenih dišnih infekcija varira u prosjeku od $30 \%^{24,25}$ pa do čak 70\% poglavito pneumonija uzrokovanih strojnom ventilacijom. ${ }^{22}$ Krauz i sur., u svojoj studiji respiratornih infekcija u JIL-u karakteristika sličnih našoj, navode stopu infekcija 8,5/1000 BI odnosno 20,1/1000 dana strojne ventilacije. ${ }^{29}$ Relativno visoka učestalost dišnih infekcija u našoj JIL mogla bi se objasniti prilično visokom prosječnom starošću bolesnika, čija je mišićna snaga često oslabljena, respiratorni obrambeni mehanizmi suprimirani, a pokazuju i tendenciju duže strojne ventilacije (Tablica 2). Infekcije mokraćnog sustava činile su $26 \%$ BI-a, slično podacima drugih studija (9\% - 39\%). ${ }^{14,18,22,24,25}$ Pojedini autori navode udio od preko $70 \%$ urinarnih infekcija od ukupnog broja. ${ }^{13}$ Suprotno velikom broju autora, u našem istraživanju dokazani uzročnici BI su i gljive (najčešće Candida albicans), što je i dokazano u čak 30\% urinarnih infekcija. Zastupljenost krvnih infekcija čini $18 \%$, što je niže u odnosu na pojedine autore koji su prijavili čak i preko $50 \%$ infekcija krvotoka. ${ }^{18}$

Najčešći uzročnici BI razlikuju se među bolnicama, ovisno o vrsti studije, dijagnozi i populaciji bolesnika. Prema podacima Američkog nacionalnog udruženja za nadzor bolničkih infekcija (NNIS - National Nosocomial Infections Surveillance System) ${ }^{4}$, od 70-tih godina prošlog stoljeća glavni uzročnici bolničkih infekcija bile su gram negativne bakterije. Prema istim autorima, gram negativne bakterije su, i početkom ovog stoljeća, bile najznačajniji uzročnik dišnih i infekcija mokraćnog sustava, ali je nastupio porast gram pozitivnih mikrorganizama kao uzročnika infekcija krvotoka i kirurških rana. Prema studiji iz 1996. godine koja je proučavala jednodnevnu prevalencu BI-a u jedinicima intenzivnog liječenja 17 zapadnoeuropskih država ${ }^{30}$, najzastupljeniji mikroorganizam je Staphylococcus aureus, ali najzastupljenija skupina su Enterobacterales. Epidemiološka studija italijanskih autora iz 2006. godine ${ }^{31}$ također navodi Staphylococcus aureus kao pojedinačnog najzastupljenijeg uzročnika, ali uz dominaciju gram negativnih mikroorganizama kao uzročnika BI u JIL koje i danas, zbog značajne zastupljenosti i razvijanja antibiotske rezistencije, predstavljaju najveći problem. ${ }^{32}$

Prema rezultatima ove studije, najčešće izolirani uzročnik BI u našem JIL-u je gram negativni Acinetobacter baumannii (27,58\% ukupnih izolata). Acinetobacter baumannii, kao poglavito oportunistički patogen, već nekoliko desetljeća predstavlja jednu od ozbiljnijih prijetnji u zdravstvenom sustavu, a uzročnik je više od četvrtine, ${ }^{33}$ ili čak polovice BI-a u JIL-u. ${ }^{34}$ Karakterizira ga rezistencija na širok spektar antibiotika, što značajno sužava mogućnosti adekvatnog tretmana. Acinetobacter baumannii može uzrokovati infekcije različitih organskih sustava. Najčešće uzrokuje infekcije dišnog sustava, pogotovo u državama Azije i Južne Amerike, gdje predstavlja jedan od tri najčešća uzročnika bakterijemija i bolničkih pneumonija. ${ }^{35}$ U našoj studiji, vidljivo je da su gram negativni mikroorganizmi glavni uzročnici respiratornih $(94,11 \%)$ i infekcija krvotoka (82,6\%), što je u skladu s većim brojem skorijih studija. $1^{5,16,22,25}$ Staphylococcus aureus, koji je bio jedan od najzastupljenijih uzročnika BI u studijama iz prošlog i početka ovog stoljeća ${ }^{17,30,31}$, činio je manje od $2 \%$ ukupno izoliranih uzročnika, što je u skladu sa studijama novijeg datuma, gdje je udio stafilokoka u nozokomijalnim infekcijama općenito znatno nižì. ${ }^{13,15,16,22}$

U našoj JIL, A. baumannii najčešće je izolirani uzročnik infekcija dišnog sustava, kao i infekcija krvotoka. Kolistin predstavlja jedini učinkovit terapijski odabir. Zbog toga zabrinjava činjenica da se, uz već postojeće mehanizme antibiotske rezistencije ${ }^{36}$ (izlučivanje $\beta$-laktamaze, aminoglikozid-modificirajućih enzima i sl.), javljaju i mehanizmi rezistencije na kolistin, ${ }^{37}$ kao i slučajevi izoliranja soja ovog patogena rezistentnog na navedeni antibiotik. ${ }^{38,39}$ Ostale gram negativne bakterije pokazuju mješovitu rezistenciju na više skupina antibiotika. Pseudomonas aeruginosa može formirati rezistenciju na većinu glavnih skupina antibiotika, pa čak i na kolistin, ${ }^{40}$ no u prikazanom je 
razdoblju naš terapijski odabir bio prilično širok, uz nekoliko dostupnih antibiotika s maksimalnim učinkom. Klebsiella pneumoniae je prethodnih desetljeća evoluirala u dva zabrinjavajuća smjera. Razvija se hipervirulentni soj koji izaziva invazivne, često diseminirane i infekcije sa stvaranjem apscesa, kako kod imunokompromitiranih, tako i kod zdravih osoba, ${ }^{41}$ ali i multirezistentni soj koji pored, sad već skoro standardnog ESBL (izlučuje $\beta$-laktamazu proširenog spektra), pokazuje i sve izraženiju karbapenemsku rezistenciju. ${ }^{42} \mathrm{U}$ proučavanom razdoblju, izolirana Klebsiela pneumoniae producirala je uglavnom ESBL, iako su, u vrijeme pisanja ovog članka, u našoj JIL dokazani prvi izolati rezistentni i na karbapeneme.

$\mathrm{Na}$ kraju, potrebno je napomenuti kako svaka zdravstvena ustanova odnosno jedinica za intenzivno liječenje ima svoju subpopulaciju najčešćih mikroorganizama s karakterističnom osjetljivošću i rezistencijom na antibiotike te je potrebno ažurno poznavanje tih karakteristika kako bi se spriječio razvoj daljnjih infekcija i odabrala odgovarajuća empirijska terapija.

\section{Zaključak}

Bolničke su infekcije uzrok povišenog morbiditeta i mortaliteta u bolničkom okruženju, a naročito $\mathrm{u}$ jedinicama intenzivnog liječenja. Glavni uzročnici BI trenutno su gram negativni mikroorganizmi među kojima dominiraju Acinetobacter baumannii i Pseudomonas aeruginosa, a najčešće BI su respiratorne infekcije. Potrebno je nastaviti s provođenjem mjera za spriječavanje širenja BI u cilju smanjenja mortaliteta i morbiditeta.

\section{LITERAT URA}

${ }^{[1]}$ Rosenthal VD, Maki DG, Salomao R, et al. International Nosocomial Infection Control Consortium. Device-associated nosocomial infections in 55 intensive care units of 8 developing countries. Ann Intern Med 2006; 145:582-91.

${ }^{[2]}$ Vincent JL. Nosocomial infections in adult intensive-care units. Lancet 2003;361:2068-77.

${ }^{[3]}$ Döcke WD, Randow F, Syrbe U, et al. Monocyte deactivation in septic patients: restoration by IFN-gamma treatment. Nat Med 1997; 3:678-81.

${ }^{[4]}$ Gaynes R, Edwards JR; National Nosocomial Infections Surveillance System. Overview of nosocomial infections caused by gram-negative bacilli. Clin Infect Dis 2005;41:848-54.

${ }^{[5]}$ Garner JS, Jarvis WR, Emori TG, Horan TC, Hughes JM. CDC definitions for nosocomial infections. Am J Infect Control 16:128-140.

${ }^{[6]}$ Pristaš I, Abram M, Bubonja Šonje M, Tićac B, Vučković D, Tambić Andrašević A. Bakteriološka dijagnostika infekcija dišnog sustava: smjernice za mikrobiološku dijagnostiku Hrvatskog društva za kliničku mikrobiologiju Hrvatskog liječničkog zbora. Zagreb: Hrvatsko društvo za kliničku mikrobiologiju; 2015.
${ }^{[7]}$ Tonkić M, Sušić E, Goić-Barišić I, Kaliterna V, Tambić Andrašević A. Bakteriološka dijagnostika infekcija mokraćnog i spolnog sustava: smjernice za mikrobiološku dijagnostiku Hrvatskog društva za kliničku mikrobiologiju Hrvatskog liječničkog zbora. Zagreb: Hrvatsko društvo za kliničku mikrobiologiju; 2017.

${ }^{[8]}$ Lee A, Mirrett S, Reller LB, Weinstein MP. Detection of bloodstream infections in adults: how many blood cultures are needed? J Clin Microbiol 2007;45:3546-8.

${ }^{[9]}$ Mehta Y, Gupta A, Todi S, et al. Guidelines for prevention of hospital acquired infections. Indian J Crit Care Med 2014;18:149-63.

${ }^{[10]}$ Rebollo MH, Bernal JM, Llorca J, Rabasa JM, Revuelta JM. Nosocomial infections in patients having cardiovascular operations: a multivariate analysis of risk factors. J Thorac Cardiovasc Surg 1996; 112:908-13.

${ }^{[11]}$ Papia G, McLellan BA, El-Helou P, et al. Infection in hospitalized trauma patients: incidence, risk factors, and complications. J Trauma 1999; 47:923-7.

${ }^{[12]}$ Alp E, Damani N. Healthcare-associated infections in intensive care units: epidemiology and infection control in low-tomiddle income countries. J Infect Dev Ctries 2015; 9:1040-5.

${ }^{[13]}$ Djordjevic Z, Jankovic S, Gajovic O, Djonovic N, Folic N, Bukumiric Z. Hospital infections in a neurological intensive care unit: incidence, causative agents and risk factors. J Infect Dev Ctries 2012; 6:798-805.

${ }^{[14]}$ Zolldann D, Spitzer C, Häfner H, et al. Surveillance of nosocomial infections in a neurologic intensive care unit. Infect Control Hosp Epidemiol 2005; 26:726-31.

${ }^{[15]}$ Sahu MK, Siddharth B, Choudhury A, et al. Incidence, microbiological profile of nosocomial infections, and their antibiotic resistance patterns in a high volume Cardiac Surgical Intensive Care Unit. Ann Card Anaesth 2016; 19:281-7.

${ }^{[16]}$ Rutkowska K, Przybyła M, Misiołek H. Health-care associated infection in the newly-opened intensive care unit. Anaesthesiol Intensive Ther 2013;45:62-6.

${ }^{[17]}$ Vosylius S, Sipylaite J, Ivaskevicius J. Intensive care unit acquired infection: a prevalence and impact on morbidity and mortality. Acta Anaesthesiol Scand 2003; 47:1132-7.

${ }^{[18]}$ Ramirez Barba EJ, Rosenthal VD, Higuera F, et al. Device-associated nosocomial infection rates in intensive care units in four Mexican public hospitals. Am J Infect Control 2006;34:244-7.

${ }^{[19]}$ Cairns S, Reilly J, Booth M. Prevalence of healthcare-associated infection in Scottish intensive care units. J Hosp Infect 2010;76:308-10.

${ }^{[20]}$ Vincent JL, Bihari DJ, Suter PM, et al. The prevalence of nosocomial infection in intensive care units in Europe. Results of the European Prevalence of Infection in Intensive Care (EPIC) Study. EPIC International Advisory Committee. JAMA 1995;274:639-44.

${ }^{[21]}$ Vincent JL, Rello J, Marshall J, et al; EPIC II Group of Investigators. International study of the prevalence and outcomes of infection in intensive care units. JAMA 2009; 302:2323-9.

${ }^{[22]}$ Simonetti A, Ottaiano E, Diana MV, Onza C, Triassi M. Epidemiology of hospital-acquired infections in an adult intensive care unit: results of a prospective cohort study. Ann Ig 2013; 25:281-9.

${ }^{[23]}$ Lossa GR, Giordano Lerena R, Fernández LE, et al. Prevalence of hospital infections in adult intensive care units in Argentina. Rev Panam Salud Publica 2008; 24:324-30. 
${ }^{[24]}$ Shaikh JM, Devrajani BR, Shah SZ, Akhund T, Bibi I. Frequen$c y$, pattern and etiology of nosocomial infection in intensive care unit: an experience at a tertiary care hospital. J Ayub Med Coll Abbottabad 2008; 20:37-40.

${ }^{[25]}$ Merzougui L, Barhoumi T, Guizani T, et al. Nosocomial infections in the Intensive Care Unit: annual incidence rate and clinical aspects. Pan Afr Med J 2018;30:143.

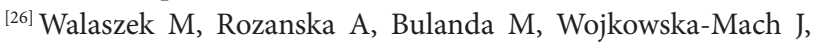
Team PSOHI3. Epidemiology of healthcare-associated infections in Polish intensive care. A multicenter study based on active surveillance. Biomed Pap Med Fac Univ Palacky Olomouc Czech Repub 2018;162:190-197.

${ }^{[27]}$ Maillet JM, Guérot E, Novara A, et al. Comparison of intensive-care-unit-acquired infections and their outcomes among patients over and under 80 years of age. J Hosp Infect 2014; 87:152-8.

${ }^{[28]}$ World Health Organization. Prevention of Hospital-Acquired Infections. A Practical Guide, 2nd ed. Geneva: WHO Press; 2002.

${ }^{[29]}$ Krauz S, Paulić D, Ivić D. Respiratorne infekcije u strojno ventiliranih bolesnika. Infektol Glasn 2017;37:37-48.

${ }^{[30]}$ Spencer RC. Predominant pathogens found in the European Prevalence of Infection in Intensive Care Study. Eur J Clin Microbiol Infect Dis 1996;15:281-5.

${ }^{[31]}$ Malacarne P, Boccalatte D, Acquarolo A, et al. Epidemiology of nosocomial infection in 125 Italian intensive care units. Minerva Anestesiol 2010;76:13-23.

${ }^{[32]}$ Villegas MV, Lyon S. Gram-negative infections: evolving treatments with expanding options. Future Sci OA. 2018; 4(9):FSO339.

[33] Žeravica K, Paulić D, Ivić D. Potrošnja antimikrobnih lijekova i prevalencija rezistentnih mikroorganizama u jedinici za intenzivno liječenje. Infektol Glasn 2017;37:9-18.
${ }^{[34]}$ Tahseen U, Talib MT. Acinetobacter infections as an emerging threat in intensive care units. J Ayub Med Coll Abbottabad. 2015;27:113-6.

${ }^{[35]}$ Wong D, Nielsen TB, Bonomo RA, Pantapalangkoor P, Luna B, Spellberg B. Clinical and Pathophysiological Overview of Acinetobacter Infections: a Century of Challenges. Clin Microbiol Rev 2017; 30:409-447.

${ }^{[36]}$ Lee CR, Lee JH, Park M, et al. Biology of Acinetobacter baumannii: Pathogenesis, Antibiotic Resistance Mechanisms, and Prospective Treatment Options. Front Cell Infect Microbiol 2017;7:55.

${ }^{[37]}$ Lee JY, Chung ES, Ko KS. Transition of colistin dependence into colistin resistance in Acinetobacter baumannii. Sci Rep 2017;7:14216.

${ }^{[38]}$ Qureshi ZA, Hittle LE, O'Hara JA, et al. Colistin-resistant Acinetobacter baumannii: beyond carbapenem resistance. Clin Infect Dis 2015;60:1295-303.

${ }^{[39]}$ Cai Y, Chai D, Wang R, Liang B, Bai N. Colistin resistance of Acinetobacter baumannii: clinical reports, mechanisms and antimicrobial strategies. J Antimicrob Chemother 2012; 67:1607-15.

${ }^{[40]}$ Rossolini GM, Mantengoli E. Antimicrobial resistance in Europe and its potential impact on empirical therapy. Clin Microbiol Infect 2008;14:2-8.

${ }^{[41]}$ Lee CR, Lee JH, Park KS, et al. Antimicrobial Resistance of Hypervirulent Klebsiella pneumoniae: Epidemiology, Hypervirulence-Associated Determinants, and Resistance Mechanisms. Front Cell Infect Microbiol 2017;7:483.

${ }^{[42]}$ Paczosa MK, Mecsas J. Klebsiella pneumoniae: Going on the Offense with a Strong Defense. Microbiol Mol Biol Rev 2016;80:629-61. 